\title{
Gestational diabetes mellitus/hyperglycaemia during pregnancy in Poland in the years 2010-2012 based on the data from the National Health Fund
}

\author{
Waldemar Wierzba ${ }^{1}$, Andrzej Śliwczyński ${ }^{2}$, Waldemar Karnafel ${ }^{3}$, \\ Iwona Bojar ${ }^{3}$, Jarosław Pinkas ${ }^{4}$ \\ 'University of Humanities and Economics in Lodz, Satellite Campus in Warsaw, Poland \\ ${ }^{2}$ Division of Public Health, Faculty of Health Sciences, Medical University of Lodz, Poland \\ 3 Institute of Rural Medicine in Lublin, Poland \\ ${ }^{4}$ Center of Postgraduate Medical Education, Warsaw, Poland
}

\begin{abstract}
Objectives: The incidence of gestational diabetes varies depending on a country and it is extremely difficult to analyse. The aim of the study was to assess the incidence of gestational diabetes in Polish population.

Material and methods: Based on the data from the National Health Fund (NHF) the authors analysed reports regarding deliveries performed and then, determined the rates of gestational diabetes/hyperglycaemia during pregnancy and pregestational diabetes in Poland in the years 2010-2012.
\end{abstract}

Results and conclusions: In Poland, the incidence of gestational diabetes was estimated to be $4.665 \%$ in $2010,6.918 \%$ in 2011 and 7.489\% in 2012. The incidence of pregestational diabetes was 1.067\% in 2010, 1.116\% in 2011 and 0.932\% in 2012.

Ginekologia Polska 2017; 88, 5: 244-248

\section{INTRODUCTION}

The presence of gestational diabetes or hyperglycaemia during pregnancy depends on many risk factors, similarly like type 2 diabetes mellitus.

After delivery, the blood glucose levels normalise in the majority of women. Criteria used to make a diagnosis of gestational diabetes were defined and described by Wilson and Jungner in 1968 [1].

The incidence of gestational diabetes varies depending on a country. The following factors affect development of hyperglycaemia during pregnancy: age, history of children with birth weight above $4000 \mathrm{~g}$, newborns with congenital defects, intrauterine deaths, arterial hypertension, being overweight or obese, familial history or type 2 diabetes mellitus, diagnosis of gestational diabetes during previous pregnancies and polycystic ovarian syndrome [2].
Gestational diabetes or hyperglycaemia during pregnancy are currently defined as any event of impaired glucose tolerance that develops during or after delivery [3]. It is difficult to determine the incidence of gestational diabetes in various populations for numerous reasons: firstly, screening tests in various countries are scheduled differently, secondly, the criteria to diagnose gestational diabetes vary depending on a country, and thirdly, the incidence of type 2 diabetes is currently greater in a younger population compared to the past, and finally, populations are different and medical care also varies depending on a country.

In the period prior to pregnancy some women used to have unknown hyperglycaemia or diabetes.

All these factors make it extremely difficult to objectively assess the incidence of gestational diabetes and hyperglycaemia during pregnancy [2]. 
Some authors agree that gestational diabetes or hyperglycaemia during pregnancy only means detection of unknown diabetes mellitus or prediabetes that was revealed during pregnancy. According to such authors the incidence of gestational diabetes is similar to the incidence of diabetes in women at the similar age but who are not pregnant [4].

Women with a history of gestational diabetes have to be monitored for known diabetes in their later period of life. According to many authors a history of gestational diabetes is a risk factor of type 2 diabetes mellitus $[5,6]$.

The incidence of gestational diabetes varies depending on a country and ranges between $3 \%$ and $6 \%$ [6].

In the United States of America the incidence of gestational diabetes is estimated to be between $1 \%$ and $14 \%$ [7].

\section{OBJECTIVES}

The aim of the work was to determine the incidence of pregestational and gestational diabetes mellitus/hyperglycaemia during pregnancy in Poland in the years 2010-2012 based on the data from the National Health Fund.

\section{MATERIAL AND METHODS}

Health services in Poland are financed by the National Health Fund (NHF) based on the act [8] and regulations of the Minister of Health that result from this act $[9,10]$. In Poland services are provided to patients as outpatient and inpatient health care. Ordinances of the NHF President present methods to organise and finance services in detail [11, 12].

In order to perform a retrospective analysis and to obtain data from report databases for statistical calculations based on the patient's unique identifiers ([Powszechny Elektroniczny System Ewidencji Ludności, PESEL] common electronic system for personal identification [13]) cases, associated with a given PESEL number, when the following medical procedures were performed, were selected from public payer's databases (JGP groups [similar to English HRG groups]): N01 - delivery; N02 - multiple or premature delivery; $\mathrm{N} 03$ - gestational or puerperial pathology 5 days; N09 - severe gestational pathology with delivery - diagnostic tests; N11 - mild gestational pathology with delivery - diagnostic tests; N13 - severe gestational pathology ended with delivery. The analysis time was determined as the period between 1.01.2010 and 31.12.2012. In total, in 2010 the NHF received reports on 388506 deliveries, in 2011 - 370.731 deliveries, and in 2012375691 deliveries.

The data presented above were correlated with reported data on the coexisting diseases in pregnant women in order to detect diagnoses of diabetes mellitus: E 10.X - insulin-dependent diabetes mellitus; E 11.X — non-insulin-dependent diabetes mellitus; E 12.X - malnutrition-related diabetes mellitus; E 13.X - other unspecified forms of diabetes mellitus; E 14.X - unspecified diabetes mellitus or a patient filled a prescription for antidiabetic agents based on the ATC classification: A 10.X (insulins), A 10 B.X (oral anti-diabetic agents) and specialist diagnostic tests to monitor blood glucose levels.

Based on this database the study cohort was stratified and the following groups were calculated: how many women in 2010, 2011 and 2012 had diabetes mellitus diagnosed prior to delivery, and how many women each year had diabetes mellitus diagnosed 365 days after delivery.

SAS, SQL and Statistica tools with the T-Student test were used for analyses.

In total, in 2010 there were (according to the NHF) 388506 deliveries, in 2011 - 370731 deliveries and in 2012 - 375691 deliveries.

In the NHF database in the period between 01.01 and 31.12.2010, between 01.01 and 31.12.2011 and between 01.01 and 31.12.2012 reports associated with diabetes mellitus with the main diagnosis of "diabetes mellitus" with the following determinants were identified: E 10.X — insulin-dependent diabetes mellitus;

E 11.X - non-insulin-dependent diabetes mellitus; E 12.X - malnutrition-related diabetes mellitus; E 13.X — other unspecified forms of diabetes mellitus; E 14.X — unspecified diabetes mellitus or in this period a patient had a prescription for any medicinal products from the group A 10.X (insulins), A 10 B.X (oral anti-diabetic agents) and specialist diagnostic tests.

The following calculations were made: how many women in each year: 2010, 2011 and 2012 had diabetes mellitus diagnosed prior to delivery, and how many women each year had diabetes mellitus diagnosed 365 days after delivery.

\section{RESULTS}

Table 1 lists the number of deliveries in Poland taking into account women with diabetes in the period 2010-2012, based on the NHF data.

In 2010 the number of deliveries in women with known diabetes was 22 270, in $2011-29$ 788, and in 2012 - 31638 deliveries.

It was not possible to determine when in women mentioned above diabetes was diagnosed: several years earlier or last year prior to delivery. This cohort also includes women with pregestational diabetes and with gestational diabetes/hyperglycaemia during pregnancy.

365 days after delivery diabetes was observed in 4148 women who gave birth in 2010, in 4139 women who gave birth in 2011 and in 3502 women who gave birth in 2012.

This cohort includes women with pregestational diabetes and also those with diabetes that developed during pregnancy. The number of women who were not diagnosed with diabetes 365 days after delivery was 18112 in 2010, 
Table 1. Absolute values of the number of deliveries in Poland, taking into account presence of diabetes mellitus known prior to delivery and within 365 days after delivery in the years 2010-2012, based on the NHF data

\begin{tabular}{|l|c|c|c|}
\hline The test groups & Year 2010 & Year 2011 & Year 2012 \\
\hline Number of all deliveries & 388506 & 370731 & 375691 \\
\hline Number of deliveries with no known diabetes & 366236 & 340943 & 344053 \\
\hline Number of deliveries in women with known diabetes before birth & 22270 & 29788 & 31638 \\
\hline $\begin{array}{l}\text { Number of deliveries in women with diabetes 365 days after delivery } \\
\text { Number of deliveries in women who were observed gestational diabetes } \\
\text { or hyperglycemia during pregnancy }\end{array}$ & 4148 & 4139 & 3502 \\
\hline
\end{tabular}

25649 in 2011 and 28136 in 2012 - these cohorts regard the number of women with gestational diabetes/hyperglycaemia during pregnancy.

In the NHF records there were no data on services regarding treatment of diabetes and reports had no information on the use of insulin, oral antidiabetic agents and strip tests to determine glucose levels in 2010 in 366236 women, in 2011 in 340943 women and in 2012 in 344053 women, respectively. In total, according to the NHF data there were reports of 388506 deliveries in 2010, 370731 deliveries in 2011 and 375691 deliveries in 2012, respectively.

Table 2 presents the rate of gestational diabetes/hyperglycaemia during pregnancy in all women who gave birth in a given year according to the NHF data in the years 2010-2012.

Among women who gave birth in 2010 gestational diabetes or hyperglycaemia during pregnancy was diagnosed in $4.665 \%$, in 2011 in 6.918\% and in 2012 in $7.489 \%$.

Table 3 presents the rates of pregestational diabetes in all women who gave birth in a given year according to the NHF data in the years 2010-2012 in Poland.

The rate of women with pregestational diabetes among all who gave birth in a given year was $1.067 \%$ in 2010 , $1.116 \%$ in 2011 and 0.932 in 2012.

\section{DISCUSSION}

As there are various methods for screening tests and various diagnostic criteria in various populations it is difficult to assess the incidence and to compare gestational diabetes or hyperglycaemia during pregnancy. There are numerous risk factors that may be identified in various ethnic groups. In the literature there have been for many years great controversies regarding criteria of diabetes and the diagnosis itself [14]. According to some authors gestational diabetes means hyperglycaemia during pregnancy.

Diabetes mellitus diagnosed during pregnancy included cases of pregestational diabetes and gestational diabetes.

According to the recommendations of the Polish Diabetes Association in the period of our observations, namely in the years 2010-2012 gestational diabetes was diagnosed based on the results of the test with a 75 g glucose loading
Table 2. The rate of gestational diabetes/hyperglycaemia during pregnancy in women who gave birth in a given year according to the NHF data

\begin{tabular}{|c|c|}
\hline Year 2010 & $4.665 \%$ \\
\hline Year 2011 & $6.918 \%$ \\
\hline Year 2012 & $7.489 \%$ \\
\hline
\end{tabular}

Table 3. The rate of pregestational diabetes in women who gave birth in a given year according to the NHF data

\begin{tabular}{|c|c|}
\hline Year 2010 & $1.067 \%$ \\
\hline Year 2011 & $1.116 \%$ \\
\hline Year 2012 & $0.932 \%$ \\
\hline
\end{tabular}

dose when the fasting glucose levels were $>100 \mathrm{mg} / \mathrm{dL}$, and at 120 minutes they were $\geq 140 \mathrm{mg} / \mathrm{dL}$ [15].

Currently, in Poland and in the United States of America (USA) gestational diabetes is diagnosed based on the test with a $75 \mathrm{~g}$ glucose loading dose using one of these criteria: fasting levels $92-125 \mathrm{mg} / \mathrm{dL}$, at 60 minutes $\geq 180 \mathrm{mg} / \mathrm{dL}$ and at 120 minutes $153-199 \mathrm{mg} / \mathrm{dL}[16,17]$.

During pregnancy all pregnant women should have diagnostic tests for carbohydrate metabolism disturbances performed, namely fasting blood glucose levels should be determined at the first visit at OB/GYN. In women in a high risk group a diagnostic test should be performed - load with $75 \mathrm{~g}$ glucose. Even when the result is normal, a diagnostic test with load with $75 \mathrm{~g}$ glucose should be performed in all pregnant women between week 24 and 28 of pregnancy.

During pregnancy hyperglycaemia is also observed as gestational diabetes mellitus, namely fasting glycaemia $\geq 126 \mathrm{mg} / \mathrm{dL}$ or glycaemia at 2 hours after load with $75 \mathrm{~g}$ glucose is $\geq 200 \mathrm{mg} / \mathrm{dL}$.

The incidence of diabetes among women aged 20-39 years was determined to be $<1 \%$ in Tanzania, $1-3 \%$ in China, $7 \%$ in the Aboriginal population in Australia, and 14-22\% in the people of Nauru [18].

The incidence of prediabetes was estimated to be below $3 \%$ in women in China, above $10 \%$ in some subpopulations 
of Afroamerican women, and above $30 \%$ in women from the Pima Indians [18].

King presented the incidence of gestational diabetes in various populations in the world. So, the mean was $4 \%$ in the USA, approximately $14.3 \%$ in a group of Indians, $6 \%$ in Mexico, 2.3\% in Italy and 3.1\% in Japan [7]. King concludes that the incidence of gestational diabetes is similar to that of type 2 diabetes mellitus [7].

According to our observations in Poland the incidence of hyperglycaemia only during pregnancy/gestational diabetes ranged between $4.665 \%$ in 2010 to $7.489 \%$ in 2012 .

Irrespective of this, in our studies diabetes mellitus that was observed 365 after delivery ranged between $1.067 \%$ in 2010 to $0.932 \%$ in 2012.

It should be assumed with some limitations that the rate of hyperglycaemia observed during pregnancy that disappeared 365 days after delivery indicates women with gestational diabetes. Moreover, it cannot be excluded that women who were diagnosed with diabetes 365 days after delivery included women with pregestational diabetes that developed during pregnancy.

Observational methods we used were not appropriate to detect women who developed type 1 and 2 diabetes mellitus during pregnancy and this constitutes a limitation to diagnose gestational diabetes or hyperglycaemia only during pregnancy. In total, in 2010 gestational diabetes was observed in Poland in $5.732 \%$ of all women who gave birth in this year. In 2011 it was $8.034 \%$ of all deliveries, and in $2012-8.425 \%$. In Poland in 2012 the rate of women with newly diagnosed diabetes was as follows:

1. In the age group of $21-30$ years $-8.451 \%$;

2. In the age group of $31-40$ years $-9.392 \%$;

3. In the age group of $41-50$ years $-7.584 \%$ [19].

In our studies the incidence of new cases of diabetes in the population of women at the age of 21 to 50 years was similar to the incidence of gestational diabetes.

A diagnosis of gestational diabetes should be carefully treated as an early phase of carbohydrate metabolism disturbances that appears during pregnancy due to changed metabolic conditions in women with risk factors of type 2 diabetes mellitus and in the future it may be associated with early development of type 2 diabetes mellitus. It has to be added that some women with hyperglycaemia during pregnancy also showed abnormal glucose tolerance during pregnancy but no diagnostic tests were performed.

Type 2 diabetes mellitus is estimated to develop in $17-63 \%$ of women with a history of gestational diabetes within 5 to 16 years after delivery. On the other hand, the incidence of type 1 diabetes mellitus in women with a history of gestational diabetes is estimated to be between $1.7 \%$ and $6.8 \%[20,21]$.
According to some authors type 2 diabetes mellitus is observed seven times more frequently in women with a history of gestational diabetes compared to those without such a history [22].

Gestational diabetes is associated with a risk of foetal macrosomia, neonatal hypoglycaemia after delivery and a higher risk of delivery via Caesarean section [23, 24]. The real incidence of gestational diabetes is not easy to determine.

In an American multicentre study (PRAMS) Desisto et al. presented the incidence of gestational diabetes among 1353810 deliveries in a group of women from 15 states and New York City in 2010 [25].

23479 women with gestational diabetes were analysed with a special questionnaire. Gestational diabetes was observed in $9.2 \%$ of women, but at the same time the presence of gestational diabetes was analysed in the same cohort of women based on birth certificates - gestational diabetes was observed in $4.6 \%$ of women [25]. The incidence of gestational diabetes in Caucasian women was $6.8 \%, 16.3 \%$ in the Asian population and $12.1 \%$ in the Latino population [25].

According to Nerup type 1 diabetes mellitus is a difficult problem for geneticists and gestational diabetes is an extremely complex problem that is not fully solvable for epidemiologists [2].

\section{CONCLUSIONS}

In Poland, the incidence of gestational diabetes/hyperglycaemia during pregnancy was $4.665 \%$ in $2010,6.918 \%$ in 2011 and $7.489 \%$ in 2012 with regard to all women who gave birth in a given year.

In Poland, the incidence of pregestational diabetes was $1.067 \%$ in 2010, 1.116\% in 2011 and $0.932 \%$ in 2012 with regard to all women who gave birth in a given year.

\section{REFERENCES}

1. Wilson JMG, Jungner F. Principles and practice of screening for diesease, Public Health Papers No 34, WHO, Geneva.

2. Ben-Haroush A, Yogev Y, Hod M. Epidemiology of gestational diabetes mellitus. In: Hod M, Jovanovic L, Dunitz M. ed. Textbook of diabetes and pregnancy. New Fetter Lane, London 2003: 64-89.

3. American College of Obstetricians and Gynecologist, Gestational Diabetes, Practice Bulletin No. 30: September 2001.

4. Harris MI. Gestational Diabetes May Represent Discovery of Preexisting Glucose Intolerance. Diabetes Care. 1988; 11(5): 402-411, doi: 10.2337/diacare.11.5.402.

5. O'Sullivan JB. Diabetes Mellitus After GDM. Diabetes. 1991; 40(Suppl. 2): 131-135, doi: 10.2337/diab.40.2.s131.

6. Coustan DR, Carpenter MW, O'Sullivan PS, et al. Gestational diabetes: predictors of subsequent disordered glucose metabolism. Am J Obstet Gynecol. 1993; 168(4): 1139-44; discussion 1144, indexed in Pubmed: 8475959.

7. King H. Epidemiology of glucose intolerance and gestational diabetes in women of childbearing age, Diabetes Care. 1998; 21(suppl. 2): B9-B13.

8. Ustawa o świadczeniach opieki zdrowotnej finansowanych ze środków publicznych z dnia 27.08.2004 roku (Dz.U. 2008 nr 164, poz. 1027 z późn. zm.).

9. Rozporządzenie Ministra Zdrowia z dnia 11 stycznia 2010 roku zmieniające rozporządzenie w sprawie świadczeń zdrowotnych gwaran- 
towanych z zakresu programów zdrowotnych (Dz. U. 2010 nr 05, poz. 29, z późn. zm.).

10. Rozporzadzenie Ministra Zdrowia z dnia 02 marca 2010 roku zmieniajace rozporządzenie w sprawie świadczeń zdrowotnych gwarantowanych z zakresu lecznictwa szpitalnego (Dz. U. 2010 nr 30, poz. 157, z późn. zm.).

11. Zarządzenie nr 101/2007/DGL Prezesa Narodowego Funduszu Zdrowia z dnia 5 listopada 2007 roku, zmieniające zarządzenie w sprawie przyjęcia "Szczegółowych materiałów informacyjnych w przedmiocie postępowania w sprawie zawierania umów o udzielanie świadczeń opieki zdrowotnej oraz o realizacji i finansowaniu umów o udzielanie świadczeń opieki zdrowotnej w rodzaju: leczenie szpitalne".

12. Zarządzenie $\mathrm{nr} 36 / 2008 / \mathrm{DGL}$ Prezesa Narodowego Funduszu Zdrowia z dnia 19 czerwca 2008 roku, w sprawie określenia warunków zawierania i realizacji w rodzaju: leczenie szpitalne w zakresie terapeutyczne programy zdrowotne.

13. http://www.msw.gov.pl/portal/pl/381/32/pesel.html.

14. Jarrett RJ. Gestational diabetes: a non-entity? BMJ. 1993; 306(6869): 37-38, indexed in Pubmed: 8435576.

15. Cukrzyca a ciąża. Zalecenia kliniczne dotyczące postępowania u chorych na cukrzycę, 2012. Diabetologia Kliniczna, 2012, tom 1, Suplement A:A41-A43.

16. Detection and diagnosis of GDM, Diabetes Care. 2014; 34(suppl. 1): 191.

17. Cukrzyca a ciąża. Zalecenia kliniczne dotyczące postępowania u chorych na cukrzycę 2016. Diabetologia Kliniczna 2016, tom 5, Suplement 1: A49-A53.

18. Diabetes and impaired glucose tolerance in women aged 20-39 years. World Health Organization Ad Hoc Diabetes Reporting Group. World Health Stat Q. 1992; 45(4): 321-327, indexed in Pubmed: 1299071.
19. Czeleko T, Śliwczyński A, Dziemidok P, et al. Cukrzyca znana w 2012 roku - ocena chorobowości na podstawie bazy danych Narodowego Funduszu Zdrowia (NFZ) w Polsce - w środowisku miejskim oraz wiejskim. Medycyna Metaboliczna. 2017; 21(1-2): 16-23.

20. Fuchtenbusch M, Ferber K, Standl E, et al. Prediction of Type 1 Diabetes Postpartum in Patients With Gestational Diabetes Mellitus by Combined Islet Cell Autoantibody Screening: A Prospective Multicenter Study. Diabetes. 1997; 46(9): 1459-1467, doi: 10.2337/diab.46.9.1459.

21. Damn P. Gestational diabetes mellitus and subsequent development of overt diabetes mellitus. Dan Med Bull. 1998; 45: 495-509.

22. Bellamy L, Casas JP, Hingorani A, et al. Type 2 diabetes mellitus after gestational diabetes: a systematic review and meta-analysis. The Lancet. 2009; 373(9677): 1773-1779, doi: 10.1016/s0140-6736(09)60731-5.

23. Wong T, Ross GP, Jalaludin BB, et al. The clinical significance of overt diabetes in pregnancy. Diabet Med. 2013; 30(4): 468-474, doi: 10.1111/dme.12110, indexed in Pubmed: 23278460.

24. Wendland E, Torloni M, Falavigna M, et al. Gestational diabetes and pregnancy outcomes - a systematic review of the World Health Organization (WHO) and the International Association of Diabetes in Pregnancy Study Groups (IADPSG) diagnostic criteria. BMC Pregnancy and Childbirth. 2012; 12(1), doi: 10.1186/1471-2393-12-23.

25. DeSisto CL, Kim SY, Sharma AJ. Prevalence estimates of gestational diabetes mellitus in the United States, Pregnancy Risk Assessment Monitoring System (PRAMS), 2007-2010. Prev Chronic Dis. 2014; 11: E104, doi: $10.5888 /$ pcd11.130415, indexed in Pubmed: 24945238.

26. Weitzman S. Weitzman S: Depistage do diabetic gestational: Le Point De Vue de L'Epidemiologiste, Journees de diabetologe. 1997; 49-54. 